\title{
MEKANISME PEMBERDAYAAN MASYARAKAT MELALUI BADAN USAHA MILIK DESA DELTA MULIA DI DESA PANEMPAN PADA MASA PANDEMI COVID-19 (Suatu Studi Mekanisme Model Dalam Pemberdayaan Masyarakat)
}

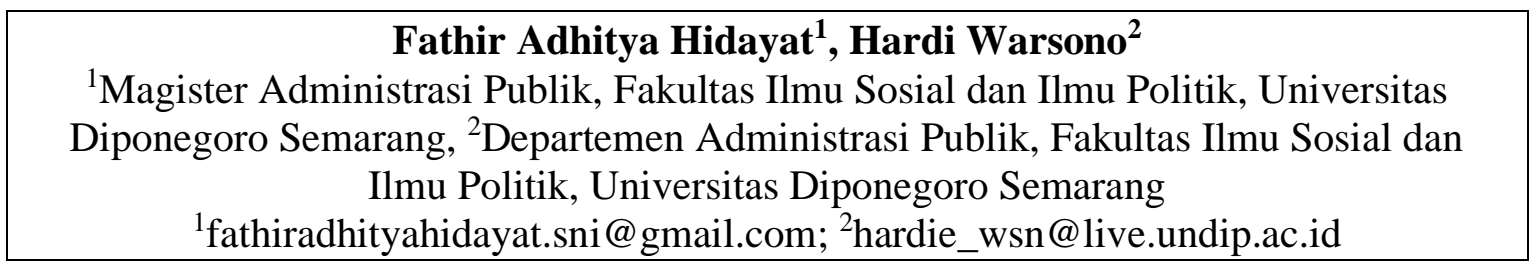

Diterima: Juni 2020; Disetujui: November 2020

\begin{abstract}
Since the COVID19 pandemic, society empowerment accomplished by VillageOwned Enterprises (BUM Desa) requires people to addressing their activity follow the changes. The empowerment mechanism carried out by BUM Desa Delta Mulia in order to face obstacles of this pandemic is quite different due to huge requirement preparation and standardization according to Government order. The aim of this research is to know the preparation model and process for empowerment society that has been done by BUM Desa Delta Mulia during COVID19 pandemic. The method is carried out by descriptive method with qualitative approach. Interview, observation, and documentation data are collected. The data source is taken from BUM Desa Delta Mulia officer. Data reduction, display, and conclusion are the way to analyze data. During the process, verification is done by author. The results show that the empowerment model mechanism conducted by BUM Desa Delta Mulia during COVID19 pandemic in the point of view preparation and the process of empowerment are good and well-standardized based on request and health protocol. However, there are some disobedient of people ignoring the protocol that had delivered by government and BUM Desa Delta Mulia.
\end{abstract}

Keywords: facilitator, infrastructure, appeal.

Abstraksi. Pemberdayaan masyarakat yang dilakukan oleh Badan Usaha Milik Desa (BUM Desa) pada masa pandemi COVID-19 menuntut setiap masyarakat untuk mengikuti perubahan-perubahan dalam aktivitasnya. Sehingga mekanisme pembedayaan yang dilakukan BUM Desa Delta Mulia dalam menghadapi tantangan dimasa pandemi ini cukup berbeda, karena banyak persiapan yang harus dipenuhi dan terstandarkan sesuai dengan himbauan Pemerintah. Tujuan dari penelitian ini adalah untuk mengetahui model persiapan dan proses pelaksanaan pemberdayaan masyarakat yang dilakukan BUM Desa Delta Mulia pada masa pandemi COVID-19. Metode yang digunakan adalah metode deskriptif dengan pendekatan kualitatif. Data dikumpulkan melalui wawancara, observasi dan dokumentasi. Sumber data diperoleh dari Pengelola BUM Desa Delta Mulia. Analisis data melalui tahapan proses reduksi data, display data, pengambilan kesimpulan. Selama proses analisis data peneliti juga melakukan verifikasi data. Hasil penelitian menunjukkan bahwa mekanisme model pemberdayaan masyarakat yang dilakukan oleh BUM Desa Delta Mulia pada masa pandemi COVID-19 ditinjau dari persiapan maupun proses dalam pelaksanaan pemberdayaan sudah berjalan dengan baik dan terstandarkan sesuai dengan himbauan serta protokol kesehatan, tetapi dalam proses pelaksanaannya masih terdapat ketidakpatuhan masyarakat yang terkesan mengabaikan himbauan yang telah disampaikan dengan baik oleh Pemerintah dan BUM Desa Delta Mulia.

Kata kunci: fasilitator, sarana prasarana, himbauan. 


\section{PENDAHULUAN}

Desa adalah suatu kesatuan hukum dimana bertempat tinggal suatu masyarakat dengan pemerintahan tersendiri. Hal ini sebagaimana yang diuraikan dalam UU Nomor 32 Tahun 2004 Pasal 1 ayat 12 Tentang Pemerintahan Daerah yang menyebutkan bahwa, Desa sebagai kesatuan masyarakat hukum yang memiliki batas-batas wilayah, yang berwenang untuk mengatur dan mengurus kepentingan masyarakat setempat, berdasarkan asal-usul dan adat istiadat setempat yang diakui dan dihormati dalam sistem pemerintahan Negara Kesatuan Republik Indonesia.

Bintaro Dalam Wasistiono (2007: 8) memandang desa dari segi geografi, yakni suatu hasil dari perwujudan antara kegiatan sekelompok manusia dengan lingkungannya. Dari pandangan itu dapat dikatakan bahwa desa merupakan suatu perwujudan atau penampakan di muka bumi yang ditimbulkan oleh unsur-unsur fisiografi, sosial ekonomis, politis dan kultural yang saling berinteraksi antar unsur tersebut dan juga dalam hubungannya dengan daerah lain. Berdasarkan pendapat Bintaro di atas diketahui bahwa desa merupakan bagian vital bagi keberadaan bangsa Indonesia, desa menjadi bagian vital karena merupakan satuan terkecil dari bangsa ini yang menunjukkan keragaman Indonesia. Dalam Murfanganti, dkk (2004:2) Selama ini keragaman bangsa Indonesia telah menjadi kekuatan penyokong bagi tegak dan eksisnya bangsa, sehingga menyadari bahwa nilai-nilai tradisional bangsa Indonesia sebenarnya sarat dengan kearifan, maka kita mempunyai kewajiban untuk menggali kearifan-kearifan budaya tersebut dan meletakkannya dalam kerangka untuk terciptanya hidup dan kehidupan selanjutnya. Hal yang demikian itu, menjadikan penguatan desa menjadi hal yang tidak bisa di tawar dan tidak bisa di pisahkan dari pembangunan bangsa ini secara menyeluruh.

Pembangunan merupakan salah satu cara untuk meningkatkan kesejahteraan masyarakat. Desa merupakan agen pemerintah yang paling depan dalam melaksanakan pembangunan, karena pembangunan ditingkat desa berkenaan langsung dengan masyarakat. Dalam mendorong pembangunan ditingkat desa, pemerintah memberikan kewenangan kepada pemerintah desa untuk mengelola potensi yang ada di daerahnya secara mandiri, salah satunya adalah melalui lembaga ekonomi yang berada di tingkat desa yakni Badan Usaha Milik Desa. Dalam mengelola potensi yang ada yaitu dengan dikeluarkannya UU Nomor 32 Tahun 2004 pasal 213 Tentang Pemerintahan Daerah yang mana menyebutkan Desa dapat mendirikan Badan Usaha Milik Desa yang di sebut BUM Desa, yang kemudian diatur lebih lanjut dalam Peraturan Menteri Desa, Pembangunan Daerah Tertinggal, dan Transmigrasi Republik Indonesia Nomor 4 tahun 2015 tentang Pendirian, Pengurusan dan Pengelolaan, dan Pembubaran Badan Usaha Milik Desa.

Badan Usaha Milik Desa (BUM Desa) merupakan lembaga usaha desa yang dibentuk oleh Pemerintah Desa melalui musyawarah desa yang kemudian dikelola oleh pengurus BUM Desa bersama-sama dengan masyarakat desa setempat. BUM Desa sendiri memiliki prinsip yang hampir sama dengan BUMD yang mengelola aset daerah dan atau BUMN yang mengelola aset nasional, hanya saja BUM Desa ruang lingkupnya jauh lebih kecil yaitu mengelola aset desa, baik fisik maupun non fisik yang sifatnya ke arah perekonomian desa. BUM Desa sebagai salah satu badan usaha yang 
beroperasi di desa haruslah memiliki perbedaan dengan badan usaha pada umumnya, hal ini dimaksudkan agar keberadaan dan kinerja BUM Desa mampu memberikan kontribusi yang signifikan terhadap peningkatan kesejahteraan warga di desa setempat.

Landasan Hukum BUM Desa dalam Undang - Undang Nomor 6 Tahun 2014 tentang Desa Pemerintahan dimuat dalam satu bab khusus mengenai BUM Desa yaitu Bab X Badan Usaha Milik Desa dalam pasal 87 yang menyatakan bahwa 1) Desa Dapat mendirikan Badan Usaha Milik Desa yang disebut BUM Desa. 2) BUM Desa dikelola dengan semangat kekeluargaan dan kegotongroyongan. 3) BUM Desa dapat menjalankan usaha dibidang ekonomi dan/atau pelayanan umum sesuai dengan ketentuan peraturan perundang-undangan. Peraturan Pemerintah No.72 Tahun 2005, dan diatur lebih rinci melalui Peraturan Menteri Dalam Negeri Nomor 39 Tahun 2010 tentang BUM Desa (Widyastuti, 2017: 31-33).

Badan Usaha Milik Desa (BUM Desa) Delta Mulia di Desa Panempan Kecamatan Pamekasan Kabupaten Pamekasan berdiri sejak tahun 2018, alamat kantor Jl. Raya Panempan (Di Dalam Area Pasar Desa Panempan). Direktur BUM Desa Delta Mulia Yaitu Hari S.E, BUM Desa Delta Mulia mempunyai 10 karyawan dalam mengelola BUM Desa Delta Mulia. Adapun Gaji setiap Pengelola BUM Desa Delta Mulia sebagai berikut:

\section{Tabel 1.}

Komposisi Gaji Pengelola Operasional dan Karyawan BUM Desa Delta Mulia

\begin{tabular}{clc}
\hline No. & Jabatan & Gaji (Rp) \\
\hline 1. & Direktur & $1.700 .000,-$ \\
2. & Sekretaris & $1.500 .000,-$ \\
\hline
\end{tabular}

\begin{tabular}{ccr}
\hline No. & Jabatan & \multicolumn{1}{c}{ Gaji (Rp) } \\
\hline 3. & Bendahara & $1.500 .000,-$ \\
4. & Karyawan & $950.000,-$ \\
\hline
\end{tabular}

Sumber: BUM Desa Delta Mulia. 2019

Kemudian jenis usaha yang dikelola oleh BUM Desa Delta Mulia sebagai Berikut:

Tabel 2.

Jenis Usaha BUM Desa Delta Mulia

No. Jenis Usaha

1. Pengelola Pasar Desa

2. Agen BRI Link

3. Pembiayaan Pola Syariah

3. (Murabaha)

Sumber: BUM Desa Delta Mulia, 2019

Dari ketiga unit usaha yang dikelola BUM Desa Delta mulia menyadari pentingnya peran pengelola BUM Desa untuk tetap memberdayakan masyarakat desa ditengah pandemi COVID-19 atau yang disebut juga dengan istilah virus corona yang melanda dunia dan di Negara Indonesia saat ini.

Pada masa pandemi COVID-19, setiap warga masyarakat diharapkan untuk mampu bertahan hidup dan menyesuaikan diri dalam pola hidup. Disiplin kolektif dan perilaku yang dipedomani protokol kesehatan dibutuhkan pada saat mereka beraktivitas, khususnya di ruang publik. Ini juga bertujuan untuk memutus mata rantai penyebaran sambil beraktivitas seperti biasa. Tetapi fakta di lapangan masyarakat masih tidak mematuhi protokol kesehatan yang telah disosialisasikan oleh kepala Desa dan Pengelola BUM Desa bahwasanya masyarakat dihimbau untuk memakai masker dan sebelum memasuki area pasar yang di dalam terdapat Kantor 
BUM Desa harus mencuci tangan terlebih dahulu. Dari pandangan itulah muncul rumusan masalah bagaimanakah mekanisme model dalam pemberdayaan masyarakat melalui BUM Desa Delta Mulia di Desa Panempan pada masa pandemi COVID-19. Oleh karena itu tujuan yang ingin dicapai antara lain: 1) Untuk mengetahui model persiapan pemberdayaan masyarakat yang dilakukan oleh BUM Desa Delta Mulia di Desa Panempan pada masa pandemi COVID-19. 2) Untuk mengetahui model proses pelaksanaan dalam pemberdayaan masyarakat yang dilakukan oleh BUM Desa Delta Mulia di Desa Panempan pada masa pandemi COVID-19.

Untuk menjawab permasalahan di atas maka peneliti menggunakan teori pemberdayaan sebagai berikut :

Menurut Rappaport dan Parsons, et al., (Dalam Mardikanto dan Soebiato, 2015: 29) Pemberdayaan adalah suatu cara agar rakyat, komunitas, dan organisasi diarahkan agar mampu menguasai atau berkuasa atas kehidupannya. Pemberdayaan adalah sebuah proses agar setiap orang menjadi cukup kuat untuk berpartisipasi dalam berbagai pengontrolan, dan mempengaruhi, kejadian-kejadian serta lembaga-lembaga yang mempengaruhi kehidupannya. Pemberdayaan menekankan bahwa orang memperoleh keterampilan, pengetahuan, dan kekuasaan yang cukup untuk mempengaruhi kehidupannya dan kehidupan orang lain yang menjadi perhatiannya.

Menurut Menurut Aziz dkk (2012: 136) Pemberdayaan masyarakat merupakan suatu proses dimana masyarakat, khususnya mereka yang kurang memiliki akses ke sumber daya pembangunan, didorong untuk meningkatkan kemandirian dalam mengembangkan perikehidupan mereka. Kemudian dalam Rosmaladewi (2018: 36) menjelaskan bahwa Pemberdayaan masyarakat merupakan sasaran dari pengembangan masyarakat, yaitu mengembangkan kondisi dan situasi sedemikian rupa sehingga masyarakat memiliki daya dan kesempatan untuk mengembangkan kehidupannya.

Tujuan pemberdayaan yaitu menunjuk pada keadaan atau hasil yang ingin di capai oleh sebuah perubahan sosial; yaitu masyarakat yang berdaya, memiliki kekuasaan atau mempunyai pengetahuan dan kemampuan dalam memenuhi kebutuhan hidupnya baik yang bersifat fisik, ekonomi, maupun sosial seperti memiliki kepercayaan diri, mampu menyampaikan aspirasi, mempunyai mata pencaharian, berpartisipasi dalam kegiatan sosial, dan mandiri dalam melaksanakan tugas-tugas kehidupannya. (Dalam Suharto, 2010: 60).

Dalam Suharto (2010: 63-64) Indikator keberdayaan yang dapat menunjukkan seseorang itu berdaya atau tidak. Keberhasilan pemberdayaan masyarakat dapat dilihat dari keberdayaan mereka yang menyangkut kemampuan ekonomi, kemampuan mengakses manfaat kesejahteraan, dan kemampuan kultural dan politis. Ketiga aspek tersebut dikaitkan dengan empat dimensi kekuasaan, yaitu : 'kekuasaan didalam' (power within), 'kekuasaan untuk' (power to), 'kekuasaan atas' (power over), dan 'kekuasaan dengan' (power with). Yang artinya keberhasilan pemberdayaan yaitu tercapainya sebuah perubahan sosial yaitu terbentuknya masyarakat yang berdaya, memiliki kekuasaan dan kemampuan dalam memenuhi kebutuhan hidupnya baik bersifat fisik, ekonomi, maupun sosial.

Dalam Rosmaladewi, (2018: 35) Pemberdayaan masyarakat pada dasarnya merupakan proses untuk membuat 
masyarakat menjadi berdaya. Setiap anggota masyarakat dalam sebuah komunitas sebenarnya memiliki potensi, gagasan serta kemampuan untuk membawa dirinya dan komunitasnya untuk menuju ke arah yang lebih baik, namun potensi itu terkadang tidak bisa berkembang disebabkan faktor-faktor tertentu. Proses pemberdayaan bisa dimaknai sebagai runtutan perubahan dalam perkembangan usaha untuk membuat masyarakat menjadi lebih berdaya.

Wilson dalam Rosmaladewi (2018: 3536) menjelaskan empat tahapan dalam proses pemberdayaan masyarakat, yaitu tahap :

1. Awakening atau penyadaran, pada tahap ini masyarakat disadarkan akan kemampuan, sikap dan keterampilan yang dimiliki serta rencana dan harapan akan kondisi mereka yang lebih baik dan efektif.

2. Understanding atau pemahaman, lebih jauh dari tahapan penyadaran masyarakat diberikan pemahaman dan persepsi baru mengenai diri mereka sendiri, aspirasi mereka dan keadaan umum lainnya. Proses pemahaman ini meliputi proses belajar untuk secara utuh menghargai pemberdayaan dan tentang apa yang dituntut dari mereka oleh komunitas.

3. Harnessing atau memanfaatkan, setelah masyarakat sadar dan mengerti mengenai pemberdayaan, saatnya mereka memutuskan untuk menggunakannya bagi kepentingan komunitasnya.

4. Using atau menggunakan keterampilan dan kemampuan pemberdayaan sebagai bagian dari kehidupan sehari-hari.

Hal yang paling penting dalam proses pemberdayaan masyarakat adalah partisipasi masyarakat. Dengan kata lain partisipasi adalah keterlibatan spontan dengan kesadaran disertai rasa tanggung jawab terhadap kepentingan kelompok untuk mencapai tujuan (Dalam Rosmaladewi, 2018: 38).

Berbicara peran dalam pemberdayaan disebutkan dalam Mardikanto (2015: 140) yaitu penyuluh/ fasilitator dengan perannya yang menjadi kewajiban dan tanggung jawab setiap penyuluh /fasilitator itu, Levin (1943) mengenalkan adanya 3 macam peran penyuluh yang terdiri atas kegiatankegiatan.

1. Pencairan diri dengan masyarakat sasaran;

2. Menggerakkan masyarakat untuk melakukan perubahan;

3. Pemantapan hubungan dengan masyarakat sasaran.

Pemberdayaan merupakan sebuah proses pengembangan agar setiap masyarakat memiliki daya dan menjadi cukup kuat untuk berpartisipasi. Adapun pemberdayaan ditinjau dari hasil penelitian terdahulu antara lain :

1. Penelitian yang dilakukan oleh Kurniawati dkk (2013) yang berjudul Pemberdayaan masyarakat dibidang usaha ekonomi, menyatakan bahwa Program yang telah dilaksanakan oleh Badan Pemberdayaan Masyarakat Kota Mojokerto khususnya pada Bidang Usaha Ekonomi meliputi bantuan perorangan dan bantuan lembaga. Setiap pelaksanaan program selalu diawali dengan tahap persiapan sebagai langkah awal pengenalan program kepada masyarakat. Tahap persiapan ini sangat penting karena dapat menentukan berhasil tidaknya program tersebut, sehingga dapat dijadikan landasan berjalannya suatu program. Kerja sama yang baik antar pemerintah 
dan masyarakat dalam melaksanakan tahap persiapan sebelum beralih ke tahap pelaksanaan sudah berjalan dengan baik. Pada tahap pelaksanaan diadakan sosialisasi kewirausahaan terkait dengan program yang akan diberikan kepada masyarakat ekonomi lemah atau mikro kecil. Dampak dari program pemberdayaan yang telah dilaksanakan oleh Badan Pemberdayaan Masyarakat Kota Mojokerto telah dapat meningkatkan kemandirian ekonomi terutama pada produktivitas dan pendapatan masyarakat yang mendapatkan bantuan, tetapi ada juga dampak buruk yang timbul dalam menjalankan usaha mereka.

2. Penelitian yang dilakukan Puji Hadiyanti (2018) berjudul Mekanisme pemberdayaan masyarakat pada kelompok daur ulang sampah DKI Jakarta, menyatakan bahwa Mekanisme dalam pelaksanaan pemberdayaan pada setiap tahapannya telah sesuai dengan tahapan dalam pelaksanaan pemberdayaan yang semestinya dilakukan sehingga dapat dikatakan terintegrasi pendidikan untuk pembangunan berkelanjutan dimana anggota kelompok selain pada kegiatan koperasi kelompok dengan nama bank sampah, juga mengikuti kegiatan mengolah sampah seperti membuat kompos dan souvenir walaupun tidak semua anggota terlibat.

3. Penelitian yang dilakukan Venita Sofiana, dkk (2016) yang berjudul Pemberdayaan Ekonomi Desa Melalui Badan Usaha Milik Desa (BUM Desa) Desa Karangjaya Kecamatan Gegerbitung Kabupaten Sukabumi, menyatakan bahwa telah diselenggarakannya workshop/ pembinaan guna mendukung sumber daya manusia dalam mengelola BUM Desa Alam Jaya. Hasil workshop menunjukkan bahwa masyarakat belum memahami bentuk pengadministrasian BUMDes yang baik dan berdasarkan dengan undang-undang sehingga kedepannya menurut hasil penelitian kami Desa Karangjaya membutuhkan pendampingan untuk pengadministrasian BUM Desa. Kemajuan dari hasil kegiatan pengabdian masyarakat ini dahulunya produk enyek yang dihasilkan oleh BUM Desa Karangjaya dijual kiloan dan menggunakan plastik tanpa pengemasan yang baik namun setelah adanya pengabdian masyarakat ini bentuk pengemasannya menjadi lebih menarik. Melakukan penjualan melalui media sosial seperti facebook (FB), Instagram (IG) dan penjualan door to door. Sebelum adanya pengabdian masyarakat ini masyarakat pengelola BUM Desa tidak mengenal Instagram sehingga di buatkan Instagram agar mempermudah dan memperbanyak penjualan melalui media massa. Survey bahan baku potensial yang dapat dikembangkan dalam BUM Desa, terlihat bahwa minat dan permintaan masyarakat yang tinggi untuk pengembangan bahan baku potensial masyarakat seperti singkong dan gula. Masyarakat Desa Karangjaya menginginkan kegiatan berkelanjutan dari BUM Desa yang telah dibuat. Seperti pengembangan singkong yang sebelumnya di buat enyek nantinya dapat diolah menjadi produk lain seperti tepung.

4. Penelitian yang dilakukan I Made Suryana, dkk (2015) yang berjudul Pemberdayaan Kelompok Tani Melalui BUM Desa (Badan Usaha Milik Desa), 
menyatakan bahwa dari program pendampingan melalui BUM Desa maka dapat disimpulkan sebagai berikut. 1. Pemanfaatan produk lokal meningkat sehingga dapat menjadi sumber pendapatan tambahan untuk kelompok wanita di Subak Anyar dan Desa Tiying Gading 2. Diversifikasi pangan juga akan tergalakkan dengan adanya pemanfaatan produk lokal, sehingga pangan yang dikonsumsi masyarakat semakin beragam dan tidak melupakan pangan lokal 3. Kepastian harga terjamin sehingga akan meningkatkan kesejahteraan masyarakat perdesaan.

Berdasarkan hasil penelitian terdahulu di atas, dapat diketahui bahwa pemberdayaan dalam mekanisme model terfokus dalam pemberdayaan program dalam tahapantahapan pemberdayaan, serta pendampingan program pemberdayaan. Keterbaruan pada penelitian ini sesuai dengan tujuan penelitian yang terfokus terhadap model pemberdayaan masyarakat pada tahapan persiapan dan proses pelaksanaan yang dilakukan oleh BUM Desa Delta Mulia pada pandemi COVID19.

\section{METODE PENELITIAN}

Jenis penelitian ini merupakan penelitian deskriptif dengan menggunakan pendekatan kualitatif. Penggunaan deskriptif kualitatif dalam hal ini bertujuan menggambarkan atau menguraikan tahapan pemberdayaan yang meliputi persiapan dan proses pelaksanaan pemberdayaan masyarakat yang dilakukan oleh BUM Desa Delta Mulia di Desa Panempan pada masa pandemi COVID-19.

$\begin{array}{lcr}\text { Fokus penelitian ini } & \text { membahas } \\ \text { mekanisme } & \text { model } & \text { pelaksanaan } \\ \text { pemberdayaan } & \text { masyarakat, } & \text { meliputi: }\end{array}$

Persiapan pelaksanaan pemberdayaan masyarakat dan proses pelaksanaan pemberdayaan masyarakat di tengah pandemi COVID-19.

Sumber data primer yang peneliti dapatkan yaitu bersumber dari Pengelola Badan Usaha Milik Desa Delta Mulia yaitu Direktur BUM Desa, Sekretaris BUM Desa dan Masyarakat desa. Adapun teknik pengumpulan data dengan cara observasi, wawancara dan dokumentasi. Kemudian teknik analisis data yang digunakan yaitu meliputi pengumpulan data, reduksi data, penyajian data serta penarikan kesimpulan (verifikasi).

\section{HASIL DAN PEMBAHASAN}

Dalam pemberdayaan masyarakat yang dilakukan BUM Desa Delta Mulia di tengah pandemi COVID-19, berdasarkan hasil observasi dan wawancara mendalam serta dokumentasi, jelas terlihat adanya pemberdayaan masyarakat dengan dibuktikan adanya aktivitas pasar dan pelayanan di kantor BUM Desa Delta Mulia yang berjalan seperti biasanya, sesuai dengan tujuan pemberdayaan. Akan tetapi dalam mekanisme pemberdayaan kali ini cukup berbeda sebelum terjadi pandemi COVID-19. Perbedaannya terletak pada mekanisme model pelaksanaan pemberdayaan.

Dalam model mekanisme pemberdayaan di tengah pandemi ini BUM Desa Delta Mulia tetap menyesuaikan dengan himbauan yang telah disampaikan oleh pemerintah kepada masyarakat ataupun himbauan Pemerintah Daerah kepada pengelola BUM Desa. Mekanisme model pelaksanaan pemberdayaan masyarakat sesuai dengan tujuan penelitian, meliputi tahapan persiapan dalam pelaksanaan pemberdayaan masyarakat dan proses 
pelaksanaan pemberdayaan masyarakat di tengah pandemi COVID-19.

\section{Persiapan pelaksanaan pemberdayaan masyarakat melalui BUM Desa Delta Mulia pada masa pandemi COVID-19}

Dalam persiapan pelaksanaan pemberdayaan masyarakat melalui BUM Desa Delta Mulia pada masa pandemi ini diawali dari turunnya Surat Edaran Pemerintah Kabupaten Nomor: 430/80/432.320/2020 tentang Tindak Lanjut Himbauan Pencegahan Penyebaran Corona Virus Disease 2019 (COVID-19), yang kemudian pemerintah desa menindaklanjuti surat edaran tersebut dengan mensosialisasikan kepada masyarakat desa termasuk kepada Pengelola BUM Desa Delta Mulia di Desa Panempan agar dapatnya pengelola BUM Desa juga mensosialisasikan surat edaran tersebut kepada masyarakat. Mengingat BUM Desa Delta Mulia dalam Program/Unit usahanya berkaitan langsung dengan masyarakat desa yaitu dalam pengelolaan Pasar Desa dan pelayanan Agen BRI Link serta simpan pinjam, sehingga dalam hal ini pengelola BUM Desa harus ikut serta mensosialisasikan kepada masyarakat Desa yang beraktivitas di area pasar Desa dan Kantor BUM Desa Delta Mulia.

Kemudian terkait dengan persiapan sarana dan prasarana dalam menunjang kebutuhan protokol kesehatan sebagai berikut :

1. Penyediaan tempat cuci tangan di setiap sudut area pasar dan Pintu Masuk Kantor BUM Desa Delta Mulia.

2. Pemberian Masker oleh pengelola BUM Desa dan Pemerintah Desa.

3. Penyediaan handsanitizer di dalam kantor BUM Desa Delta Mulia.

4. Penyemprotan disinfektan dengan berkoordinasi bersama Pemerintah dan
Relawan Satgas COVID-19 yang ingin melakukan penyemprotan di area pasar.

5. Pengukur suhu tubuh/thermometer di area pasar dan kantor BUM Desa Delta Mulia oleh petugas.

\section{Proses pelaksanaan pemberdayaan masyarakat melalui BUM Desa Delta Mulia pada masa pandemi COVID-19 \\ Dalam proses pelaksanaan} pemberdayaan masyarakat melalui BUM Desa Delta Mulia pada masa pandemi ini sebagaimana yang telah disiapkan terkait sarana dan prasarana sesuai dengan protokol kesehatan yang telah disebutkan di atas dan dalam proses pelaksanaan seperti biasa masyarakat beraktivitas dipasar dan kantor BUM Desa Delta Mulia tetap melayani masyarakat yang ingin melakukan pembayaran listrik, transfer uang, dan pembayaran lainnya melalui unit usaha yang dikelola BUM Desa Delta Mulia yaitu Agen BRI Link serta kepentingan masyarakat lainnya yang berkaitan dengan kantor BUM Desa Delta Mulia. Tetapi setelah dilakukan pengamatan oleh peneliti, sebagian masyarakat yang beraktivitas di area pasar dan kantor BUM Desa Delta Mulia tidak mematuhi himbauan yang telah disosialisasikan oleh Pemerintah Daerah dan Kepala Desa serta himbauan langsung dari pengelola BUM Desa kepada masyarakat pengunjung pasar.

Dalam proses pelaksanaan masih terdapat pengabaian dari masyarakat terkait himbauan Protokol kesehatan. Dari himbauan protokoler yang paling tidak dipatuhi dan terkesan diabaikan oleh masyarakat pengunjung pasar yaitu penggunaan masker saat beraktivitas di area pasar, dikarenakan masyarakat dikala menggunakan masker merasa pernafasannya terganggu dan juga masyarakat tidak mematuhi himbauan untuk mencuci tangan dikala keluar dan 
masuk saat berkunjung ke pasar Desa maupun ke Kantor BUM Desa Delta Mulia.

Berdasarkan hasil penelitian sebagaimana diuraikan di atas, maka dapat dikatakan bahwa dalam rangka penyederhanaan mekanisme model pemberdayaan masyarakat dilakukan mulai dari tahap persiapan dan tahap pelaksanaan dalam proses pemberdayaan. Tahap persiapan pemberdayaan masyarakat yang dilakukan oleh BUM Desa Delta Mulia di tengah pandemi Covid-19 sesuai dengan konsep tujuan pemberdayaan. Kesesuaian tujuan sebagaimana yang dinyatakan Suharto (2010: 60) yaitu masyarakat yang berdaya, memiliki kekuasaan atau mempunyai pengetahuan dan kemampuan dalam memenuhi kebutuhan hidupnya baik yang bersifat fisik, ekonomi, maupun sosial. Artinya pemberdayaan yang dilakukan oleh BUM Desa Delta Mulia ditengah pandemi mencerminkan kepedulian BUM Desa akan keberdayaan masyarakat dalam memberikan ruang untuk tetap beraktivitas dalam pemenuhan kebutuhannya atau keberlangsungan hidupnya. Hal ini dibuktikan dengan adanya persiapan yang diberikan oleh pengelola BUM Desa dalam keberlangsungan pemberdayaan masyarakat di tengah Pandemi.

Perencanaan kegiatan epidemiologi dimulai dari persiapan yang merupakan langkah awal sebelum dilaksanakan suatu kegiatan (Aziz dan Jufri, 2015: 88). Kemudian Menurut Susanto (2016: 37) Persiapan pemberdayaan merupakan langkah awal dari tahap pemberdayaan yang harus dilakukan. Artinya ditinjau dari pandangan tersebut di atas, persiapan dalam pelaksanaan pemberdayaan merupakan tahapan atau langkah awal yang harus dilakukan sebelum melaksanakan proses pemberdayaan, sehingga dalam hal ini BUM Desa Delta Mulia telah memfasilitasi kebutuhan-kebutuhan yang diperlukan dalam persiapan sesuai dengan standar protokol kesehatan di masa pandemi COVID-19.

Pengelola BUM Desa Delta Mulia sebagai aktor yang mempunyai peran dalam pelaksanaan pemberdayaan yang dapat disebut sebagai penyuluh atau fasilitator (Mardikanto, 2015: 140-141), sedangkan menurut Lippit menyatakan bahwa peran fasilitator yaitu pengembangan kebutuhan untuk melakukan perubahan-perubahan, dalam tahapan ini setiap fasilitator harus mampu memainkan perannya pada kegiatan-kegiatan salah satunya diagnosa masalah atau kebutuhan-kebutuhan yang benar-benar diperlukan (real need) masyarakat penerima manfaat.

Ditinjau dari pandangan tersebut di atas dapat dikatakan bahwa pengelola BUM Desa Delta Mulia mempunyai peran sebagai fasilitator. Peran fasilitator dalam aktivasinya dapat memberikan fasilitas sesuai pemenuham kebutuhan-kebutuhan yang terstandarkan dalam aktivitas pemberdayaan masyarakat ditengah pandemi COVID-19. Hal yang demikian dapat diartikan bahwa BUM Desa telah memainkan perannya sebagai fasilitator yang akomodatif dalam kepentingan pemberdayaan sesuai dengan kebutuhankebutuhan yang diperlukan dalam proses kegiatan pemberdayaan.

Dalam Proses pelaksanaan pemberdayaan menurut pandangan Rosmaladewi (2018: 35-38) adalah bahwa proses pemberdayan bisa dimaknai sebagai runtutan perubahan dalam perkembangan usaha untuk membuat masyarakat menjadi lebih berdaya. Hal yang paling penting dalam proses pemberdayaan masyarakat adalah partisipasi masyarakat. Dengan kata lain partisipasi adalah keterlibatan spontan dengan kesadaran disertai rasa tanggung 
jawab terhadap kepentingan kelompok untuk mencapai tujuan.

Memperhatikan pandangan sebagaimana yang dinyatakan Rosmaladewi di atas dapat ditangkap bahwa dalam proses pelaksanaan pemberdayaan sebagai runtutan perubahan untuk menjadi berdaya, dan partisipasi menjadi hal yang penting dalam proses pemberdayaan, sehingga dapat diartikan dalam proses pemberdayaan yang dilakukan oleh BUM Desa Delta Mulia pada masa pandemi ini telah memfasilitasi dalam perubahan-perubahan aktivitas masyarakat yang bertujuan untuk masyarakat tetap berdaya, serta agar terhindar dari penyebaran virus COVID-19. Akan tetapi partisipasi dalam perubahan yang dilakukan oleh masyarakat terkesan mengabaikan atau dalam arti tidak mengindahkan himbauan yang telah disosialisasikan oleh pemerintah maupun pengelola BUM Desa Delta Mulia. Dengan tidak mengikuti himbauan dari pemerintah bisa berdampak pada hal yang tidak dikehendaki.

Pada proses pelaksanaan pemberdayaan dalam konteks peran yang dilakukan oleh BUM Desa sebagaimana yang disebut fasilitator menurut Lippit sebagaimana dikutip Mardikanto (2015: 140-141) menyatakan bahwa peran fasilitator adalah menggerakkan masyarakat untuk melakukan perubahan. Perubahan yang harus dilakukan dengan menunjukkan masalah-masalah, serta memimpin dalam mengarahkan dan membimbing perubahanperubahan yang sudah direncanakan atau dipersiapkan.

Oleh karena itu dapat dikatakan bahwa proses pelaksanaan pemberdayaan yang dilakukan oleh pengelola BUM Desa Delta Mulia sudah melaksanakan perannya dari menyiapkan kebutuhan sesuai himbauan pemerintah. Kesesuaian himbauan pemerintah yang dilakukan oleh pengelola BUM Desa berupa penyediaan protokol kesehatan yang terstandarkan. Namun dalam keberlangsungan pelaksanaan pemberdayaan, masyarakat masih enggan atau terkesan mengabaikan himbauan untuk melaksanakan segala aktivitas sesuai protokoler dalam proses pemberdayaan. Artinya peran yang dimainkan oleh pengelola BUM Desa Delta Mulia sudah baik dalam menggerakkan masyarakat untuk melakukan perubahan aktivitasnya dikala berkunjung ke pasar, akan tetapi masyarakatlah yang masih kurang dapat memahami artikulasi pengetahuan akan perubahan dalam aktivitasnya pada saat pandemi COVID-19.

\section{SIMPULAN}

Mekanisme dalam pelaksanaan pemberdayaan masyarakat pada masa pandemi COVID-19 oleh pengelola BUM Desa Delta Mulia sebagai fasilitator pemberdayaan telah melakukan sebagaimana mestinya, mulai dari mempersiapkan sarana-prasarana kebutuhan yang terstandarkan sesuai protokol kesehatan, dan himbauan dalam proses pemberdayaan. Tetapi dalam proses pelaksanaannya masih terdapat ketidakpatuhan masyarakat, yang terkesan mengabaikan akan himbauan yang telah disampaikan oleh Pemerintah dan pengelola BUM Desa Delta Mulia. Oleh karena itu maka, untuk mencapai tujuan pemberdayaan harus tetap memperhatikan pola pengelolaan dan memberikan edukasi dalam model mekanisme alur program sebagai representasi pemberdayaan dan sosialisasi serta himbauan secara terus menerus kepada masyarakat agar masyarakat lebih disiplin mematuhi himbauan sesuai protokol kesehatan dalam upaya memutus rantai penyebaran virus. 


\section{DAFTAR PUSTAKA}

Aziz. Jufri. 2015. Implementasi Aparatur Sipil Dalam Bidang Kesehatan Untuk Pembinaan Karir Jabatan Fungsional Epidemiologi Kesehatan. Yogyakarta: Global Press.

Mardikanto, Totok. Soebiato, Poerwoko. 2015. Pemberdayaan Masyarakat Dalam Perspektif Kebijakan Publik. Bandung: Alfabeta.

Murnfangati, titi. Murniatmo, Gatut. Sunjata, Pantja. Sumarsih, Sri. Susilantini Endah. Ariani, Christriyani. 2004. Kearifan Lokal di Lingkungan Masyarakat Samin, Kabupaten Blora, Provinsi Jawa Tengah. Yogyakarta : Kementrian Kebudayaan dan Pariwisata Deputi Pelestarian dan Pengembangan Kebudayaan Balai Kajian Sejarah dan Nilai Tradisional.

Rosmaladewi, Okke. 2018. Manajemen Kemitraan Multistakeholder Dalam Pemberdayaan Masyarakat. Yogyakarta : CV Budi Utama.

Suharto, Edi. 2010. Membangun Masyarakat Memberdayakan Rakyat "Kajian Strategi Pembangunan Kesejahteraan Sosial dan Pekerjaan Sosial”. Bandung : PT. Refika Aditama.

Sulistiyani, Ambar Teguh. 2004. Kemitraan dan Model-model Pemberdayaan. Yogyakarta : Graha Ilmu.

Susanto, Ahmad. 2016. Konsep, Strategi, dan Implementasi Manajemen Peningkatan Kinerja Guru. Jakarta : Prenada Media.

Winarni, Tri. 1998. Memahami Pemberdayaan Masyarakat Desa Partisipatif dalam Orientasi Pembangunan Masyarakat Desa Menyongsong Abad 21 : Menuju Pemberdayaan Pelayanan Masyarakat. Yogyakarta : Adita Media.

Widyastuti, Yuli. 2017. Peran Badan Usaha Milik Desa (BUMDES) Terhadap Kesejahteraan Masyarakat Pujokerto Kecamatan Trimurjo Kabupaten Lampung Tengah Perspektif Ekonomi Islam. Lampung : Universitas Ekonomi dan Bisnis Islam Negeri (UIN) Raden Intan Lampung.

Wasistiono, Sadu. Tahir, Irwan. 2007. Prospek Pengembangan Desa. Bandung : CV. Fokus Media.

Hadiyanti, Puji. 2018. Mekanisme Pemberdayaan Masyarakat Pada Kelompok Daur Ulang Sampah Di DKI Jakarta. Jakarta : Jurnal Ilmu Pendidikan, Keguruan, dan Pembelajaran.

Kurniawati, Dwi Pratiwi. Supriyono, Bambang. Hanafi, Imam. 2013. Pemberdayaan Masyarakat di Bidang Usaha Ekonomi (studi pada badan Pemberdayaan Masyarakat Kota Mojokerto. Malang : Jurnal Administrasi Publik.

Kuncahyawati, Helina. 2016. Pemberdayaan Pasar Tradisional dan pedagang Pasar Menurut Peraturan Daerah Kabupaten Purworejo Nomor 6 Tahun 2014 (Studi Kasus : Pasar Krendetan).Yogyakarta : Universita Muhammadiyah Yogyakarta.

Rahmadanik, Dida. 2018. Peran BUMDES Dalam Pemberdayaan Masyarakat Desa Cokrokembang Kecamata Ngadirojo Kabupaten Pacitan. Surabaya : Jurnal Universitas 17 Agustus. 
Sofiana, Venita. Saepuloh, Luthpi. Eriswanto, Elan. 2016. Pemberdayaan Ekonomi Desa Melalui Badan Usaha Milik Desa (BUMDes) Desa Karangjaya Kecamatan Gegerbitung Kabupaten Sukabumi. Purwokerto : Universitas Muhammadiyah Sukabumi.

Suryana, I Made. Setiyono, Tri Joko. Murdoyuwono, Sri. 2015. Pemberdayaan Kelompok Tani Melalui BUMDES (Badan Usaha Milik Desa). Denapasar : Jurnal Bakti Saraswati.

Wahyuni, Dinar. 2018. Strategi Pemberdayaan Masyarakat Dalam Pengembangan Desa Wisata Nglanggeran, Kabupaten Gunung Kidul. Jakarta : Jurnal Masalah-Masalah Sosial.

Widjajanti, Kesi. 2011. Model Pemberdayaan Masyarakat. Semarang : Jurnal Ekonomi Pembangunan.

UU Nomor 6 Tahun 2014 Tentang Desa.

Peraturan Menteri Desa, Pembangunan Daerah Tertinggal, dan Transmigrasi Republik Indonesia Nomor 4 tahun 2015 tentang Pendirian, Pengurusan dan Pengelolaan, dan Pembubaran BadanUsaha Milik Desa.

Peraturan Menteri Dalam Negeri Nomor 39 Tahun 2010 Tentang Badan Usaha Milik Desa. 